\title{
Determinants Skills for Vocational Educators Success
}

\author{
Sucipto, Tugino \\ \{sucipto@mail.unnes.ac.id, tugino@mail.unnes.ac.id\} \\ Civil Engineering Faculty, Semarang State University
}

\begin{abstract}
Vocational education aims to developing the knowledge, abilities, skills and competence formation of each individual. Vocational education must have characteristics in which individual performance is oriented in the world of work, special justifications for needs in the industrial world, focus on curriculum development in which there are cognitive, psychomotor and affective aspects, benchmarks for success are not limited to academics but the development of skills, sensitivity the development of the world of work, especially those based on technology, requires adequate and adequate support facilities as well as the existence of human resources support. On the other hand, the biggest challenge in facing industry 4.0 by developing learning systems, education units, students, and the educators and education staff needed. The purpose of this research is to describe in depth the role of creative, critical and solutions thinking skills that must be possessed by vocational educators in the industrial era. This research is a quantitative research. Primary data in this study are the results of a questionnaire, while secondary data obtained through supporting documents that are the results of observation and interviews. This research was conducted in the civil engineering education department of UNNES. Data was collected through filling out questionnaires and then the data were analyzed using SPSS to find out how far the influence of creative, critical and solutions thinking skills on the success of vocational educators in learning. The results showed a significant influence between creative thinking, critical and solutive to the success of teaching learning process.
\end{abstract}

Keywords: creativity, critical thinking, Solving Problem, success.

\section{Introduction}

Vocational education is undergoing metamorphose very quickly. Vocational education is a work that is needed in the future. A person who graduated from vocational education must have some special skills to achieve success in the world of work later. No exception for prospective teachers from civil engineering education that is because later the workforce of civil engineering graduates is someone who masters a field that inherently broadly covers various technical fields that 
contribute to infrastructure, public health, and safety. Civil engineers must have technical breadth and strong problem-solving skills in various technical fields from civil engineering disciplines [1]. Therefore when they are still prospective civil engineering teachers they need to master some skills, knowledge, and behavior [2]

Schools and companies will need a workforce that has competitiveness in the labor market; quality assurance requirements and soft skills; scientific and technological development [3]. Based on research results, a graduate from civil engineering and civil engineering education must have good interpersonal skills [4]. Engineering graduates face critical problems during the transition from university to an engineering career. Civil engineering graduates and civil engineering education experience problems when they work, especially when communicating and solving problems that are still rather slow [5].

Critical thinking is very important to be owned by a teacher because critical thinking is considered by some people as a meta-skill needed by humans in integrating practice and technology [6]. Even a civil engineering teacher must have strong, high cognitive, and good interpersonal skills [7]. Christian thinking becomes a bridge in facing the times that are so fast and full of challenges [8]. Critical thinking is not only the ability to summarize what reading is. Critical thinking is the ability to explain and evaluate an argumentation as well as analyze and conclude a problem and provide assumptions / assumptions. Critical thinking skills are basically competencies that are intertwined in which an individual can explain and evaluate arguments, critical questions, or discourse in terms of: (a) problem / question, (b) goals / objectives, (c) inference / argumentation, (d ) evidence / information, (e) concepts / ideas, (f) nature of assumptions / assumptions, (g) types of assumptions, (h) implications / consequences, (i) point of view, and (j) criteria for reasonableness [9].

Creativity seems to be one of the core components of this new capability and is considered an asset for the development community. Although creativity is widely recognized as an Asset for the community, it remains a vague concept and there are many definitions of this competency in the literature [10] of teachers and business and education experts. The skills that must be mastered by students majoring in civil engineering education are learning skills and innovation (creativity, 
critical thinking, communication, and collaboration), technological and digital skills, life and career skills (social and emotional competence to succeed in life and work environment). Creativity needs to be integrated in every curriculum in tertiary institutions [11]. Developing creative potential requires time and patience. If prospective teachers have creativity during college, the teacher will be able to integrate teaching that is more easily creative in the classroom.

One indicator of intellectual behavior is the ability to solve problems (problem solving)[12]. Civil engineering education students are expected to have adequate problem solving skills, so that they will help students solve academic and non-academic problems. In addition, with adequate problem solving skills will facilitate students in dealing with work situations that are full of various problems that must be resolved. The lack of problem solving skills in students is also shown by complaints from the world of work that many complain about college graduates who seem unprepared to face the world of work and are still often confused when faced with problems and are required to solve these problems. The lack of ability to overcome problems in the world of work is due to the quality of college graduates who are considered inadequate in terms of the ability to think divergent, which is needed in solving problems.

\section{Method}

The research approach used is qualitative by using descriptive research. The study was conducted at Education of Civil Engineering Department in UNNES. Researchers collected information from the students, then researchers analyzed the important factors to get success in world work. The primary and secondary research data collection techniques used unstructured interviews with student of education of civil engineering department. The instrument of this research consist of the following: (1) is creativity needed for civil engineering educator's candidates? (2) Is critical thinking skill needed to mastering by civil engineering educators candidates? (3) Is problem solving ability needed to mastering by civil engineering educator's candidates? (4) What is another factors should mastery by civil engineering educator's candidates? It uses educators because they are considered to understand most of what researchers are expected to test the validity of data in the form of interviews. The study population consists of 40 civil engineering educators' candidates. The 
researcher uses triangulation technique on sources. To test the validity of the research instruments which were in the form observations, the researcher first determined what theory or concept will be used as a reference for the interview. The concept or theory is then categorized into several indicators used to serve as operational benchmarks. Regarding the reliability test in the interview instrument, there is more emphasis on the constancy of results raised by the sources. Reliability of observation instruments was based on rules/guidelines made by researchers and tracked at the time of observation. Data analysis technique from the data source of informants' interview results of civil engineering educator's candidates used field data analysis model of interactive analysis models from Miles and Huberman, where the stages of data collection, data presentation, data reduction, and conclusion are completed simultaneously with the process of collecting data and interacting with each other. On the other hand, data analysis of the results of observation was done through a checklist method.

\section{Results and Discussion}

Critical thinking, creativity and problem solving are the main keys to achieving success in the world of work. Based on the results of the questionnaire given shows that civil engineering education students argue affect success in the world of work, namely critical thinking has a role of $30 \%$, creativity has a role of $25 \%$, and problem solving that determines success in the world of work is problem solving has a role of $35 \%$. While the remaining $10 \%$ is found there are other factors that influence the level of success when in the world of work. 


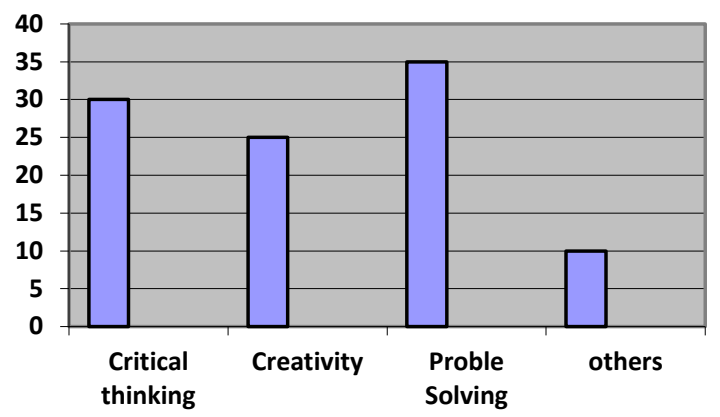

Fig. 1. Diagram of percentage of determinants skills

Based on the diagram above, it can be analyzed that among the three skills analyzed, the results of the questionnaire show that critical thinking has an effect of as much as $30 \%$ in achieving success in the world of work, that is because critical thinking is needed in the world of work in providing arguments or analyzing things that need to be updated in the learning process. While creativity gets a percentage of $25 \%$. High creativity can be useful when in the world of work to bring up ideas, ideas and innovations in the learning process, so learning becomes more enjoyable and students can absorb quickly the material presented so that student achievement can increase. Teacher's performance is very good. Problem solving gets a percentage of $35 \%$ higher than the other two skill factors. Problem solving is really needed in the world of work, because with very good problem solving skills can make decisions and solutions in every problem precisely and quickly. While $10 \%$ are influenced by other factors such as cooperation, good communication, networking, digital literacy skills. These other factors also require attention when lectured.

\section{Critical Thinking}

As prospective educators at the level of vocational education units apparently have to have very high critical thinking skills, because they can affect the level of success in the future. Critical thinking can be used to vary ideas about critical thinking that makes it difficult for educators to plan instructions for teaching and assess critical thinking in their students. The education curriculum is hinted at in all disciplines but does not appear to be fully formed [13]. Critical Thinking is emphasized in education, lecturers can provide repeated and varied exercises in thinking exercises 
to prospective civil engineering education teachers, teaching students to analyze the difference between evidence and conclusions. The lecturer supports students to be bold in arguing in class discussions. The lecturer asks students to analyze the papers and correct if there is anything wrong [14].

These strategies can help students become more independent thinkers. Lecturers can regularly give questions to students in a Socratic way by exploring the various dimensions of their thinking, including their goals, the purpose of their evidence, reasons, data, claims, beliefs, their interpretations, deductions, conclusions, implications and consequences of their thinking, and responses they. Critical thinking has been defined philosophically and psychologically by many authors [15]. In fact, from a psychological point of view, critical thinking can influence the cognitive development of students and critical arguments that point to a problem [16]. Cognitive perspectives with high critical thinking skills will benefit when civil engineering education students organize instructional mental activities depending on their level of difficulty in the classroom context, analyzing problems, ability to organize and compare information, synthesis, gathering information and evaluating, and making information judgments [17].

\section{Creativity}

Introducing creative teaching in the classroom can bring benefits such as developing children's imagination [18] and increasing the probability for large discoveries and economic development for the future [19]. Creativity is also considered as an important component of personal well-being [20] and creativity can also develop curiosity, openness, and communication skills [21]. Creative and critical thinking are the two competencies that have received more and more attention this past year, especially, because of the need to develop information and communication technology in schools. In fact, the digital revolution brought new problems to education, in particular, the impact of new technologies means that changes in everyday life often occur and it is necessary for individuals to adapt to this situation. Also the use of the internet by children means they must choose information from various sources and know how to use information in a useful way.

3. Problem solving skills

Problem solving is a cognitive skill that is complex, and perhaps the most intelligent ability possessed by humans [22]. This is because when solving problems, students not only need to think, 
but they need to think critically to be able to see a problem and think creatively to be able to solve the problem. Skills in problem solving need to be sharpened during the learning process, because later after being in the world of work, civil engineering education students will encounter many problems that must be given a solution immediately and appropriately. It cannot immediately appear but must begin to get used to since college. Skill and precise problem solving will greatly support their performance when in the world of work. Making policies and making decisions appropriately can remind their professionalism and have a good impact on the agencies where they work.

\section{Conclusion}

Critical thinking is needed in the world of work in providing arguments or analyzing things that need to be updated in the learning process. High creativity can be useful when in the world of work to bring up ideas, ideas and innovations in the learning process, so learning becomes more enjoyable and students can absorb quickly the material presented so that student achievement can increase. Teacher's performance is very good. Problem solving is really needed in the world of work, because with very good problem solving skills can make decisions and solutions in every problem precisely and quickly. In addition to the three dominant factors, there are other factors such as collaboration, good communication, networking, digital literacy skills. These other factors also require attention when lectured. All factors that influence the success of teaching staff in the work

world can be integrated directly into the learning process in each subject, so students are ready to enter the workforce and have the provisions to achieve success in the work world.

\section{References}

[1] CE BOK (Civil Engineering Body of Knowledge) for the 21st Century-Preparing the Civil Engineer for the Future. Second Edition, 2008 \& CE BOK 3rd edition DRAFT March (2018). http://www.asce.org/civil_engineering_body_of_knowledge/ 
[2] ABET (ABET Criteria for Accrediting Engineering Programs) (2015).available via http://www.abet.org/accreditation/accreditation-criteria/criteria-for-accrediting-engineeringprograms-2016-2017/.

[3] Al Munifi, A. (2018). Current Trends in Engineering Education, Seminar at the Unaizah College of Engineering. Qassim University. Saudi Arabia.

[4] Itani, M. and Srour, I. (2015) Engineering Students' Perceptions of Soft Skills, Industry Expectations, and Career Aspirations, American Society of Civil Engineers.

[5] Baytiyeh, H. and Naja, M. (2012) Identifying the challenging factors in the transition from colleges of engineering to employment, European Journal of Engineering Education, Vol. 37, No. 1, 3-14 https://doi.org/10.1080/03043797.2011.644761

[6] Nurius, P. S. (1995). Critical thinking: A meta-skill for integrating practice and information technology training. In J. Rafferty, J Steyaert, \& D. Columbi (Eds.), Human Services in the Information Age (pp. 109-126). Binghamton, NY: Haworth Press.

[7] Strauser, D., \& Lustig, D. (2001). The implications of posttraumatic stress disorder on vocational behavior and rehabilitation planning. Journal of Rehabilitation, 67(4), 26-30.

[8] Muirhead, B. (2007). Integrating creativity into online university classes. Education, Technology and Society, 10(1), 1-13.

[9] Paul, R., \& Elder, L. (2003). The miniature guide to critical thinking: Concepts and tools. Dillon Beach, CA: The Foundation for Critical Thinking.

[10] R. J. Sternberg, "Teaching for creativity: The sounds of silence," Psychology of Aesthetics, Creativity, and the Arts, vol. 9, no. 2, pp. 115-117, 2015.

[11] M. Binkley, O. Erstad, J. Herman et al., "Defining twenty-first century skills," in Assessment and Teaching of 21st Century Skills,B. McGaw and E. Care, Eds., pp. 17-66, Springer, New York, NY, USA, 2012

[12] Gokhale. Anuradha A. 1995. Collaborative Learning Enhances Critical Thinking. Journal Of Technologi Education. Vol 7. No 1.

[13] M. Besanc, on and T. Lubart, La creativit ' e de l'enfant ' , Mardaga, Wavre, Belgium, 2015. [14] Mulnix, Wilson Jennifer. (2010). Thinking Critically about Critical Thinking. Journal of Educational Philosophy and Theory. Vol. 10.1111.pp 14

[15] C. P. Dwyer, M. J. Hogan, and I. Stewart, "An integrated critical thinking framework for the 21 st century," Thinking Skills and Creativity, vol. 12, pp. 43-52, 2014.

[16] M. A. Ab Kadir, "What teacher knowledge matters in effectively developing critical thinkers in the 21st Century curriculum?" Thinking Skills and Creativity, vol. 23, pp. 79-90, 2017.

[17] B. S. Bloom, Taxonomy of education objectives?: the classification of educational goals. Handbook 1?: cognitive domain, McKay, New York, NY, USA, 1956.

[18] R. Cachia, A. Ferrari, K. Ala-Mutka, and Y. Punie, Creative learning and innovative teaching: final report on the study on creativity and innovation in education in the EU member states, Institute for Prospective Technological Studies, Seville, Spain, 2010. 
[19] R. J. Sternberg, "Teaching for creativity: The sounds of silence," Psychology of Aesthetics, Creativity, and the Arts, vol. 9, no. 2, pp.115-117, 2015.

[20] J. A. Plucker, R. A. Beghetto, and G. T. Dow, "Why isn't creativity more important to educational psychologists? Potentials, pitfalls, and future directions in creativity research," Educational Psychologist, vol. 39, no. 2, pp. 83-96, 2004.

[21] L. L. S. Dunn, Cognitive playfulness, innovativeness, and belief of essentialness: characteristics of educators who have the ability to make enduring changes in the integration of technology into the classroom environment [Unpublished doctoral dissertation], University of North Texas, 2004 